\title{
Tumescent Local Anesthesia: A Systematic Review of Outcomes
}

Yu Liu, BA*1,2, Sanjana Lyengar, MD*3 ${ }^{* 3}$ Chrysalyne D Schmults, MD, MSCE ${ }^{1}$; Emily S Ruiz, MD, MPH ${ }^{1}$; Robert Besaw, MPH ${ }^{1}$; Laura K Tom, MD ${ }^{4}$; Michelangelo Giovanni Vestita, MD ${ }^{5}$; Jason Kass, MD, $\mathrm{PhD}^{6}$; Abigail $\mathrm{H}$ Waldman, $\mathrm{MD}^{1}$

*Co-first authors for this work

Author Affiliations:

1. Department of Dermatology, Brigham and Women's Hospital, Harvard Medical School, Boston, Massachusetts (Liu, Besaw, Ruiz, Waldman, Schmults)

2. Saint Louis University School of Medicine, Saint Louis, Missouri (Liu)

3. Department of Dermatology, West Virginia University, Morgantown, WV

4. Department of Plastic and Reconstructive Surgery, MedStar Washington Hospital Center, Georgetown University School of Medicine (Tom)

5. Division of Plastic and Reconstructive Surgery, Department of Emergency and Organ Transplantation, University of Bari, Bari, Italy

6. Reliant Medical Group, Worchester, MA (Kass)

Corresponding Author: Abigail H Waldman MD

Department of Dermatology, Brigham and Women's Hospital, Harvard Medical School, Boston, MA 02115 (awaldman10@bwh.harvard.edu) 


\begin{abstract}
IMPORTANCE: Tumescent local anesthesia (TLA, whereby anesthesia is achieved by injection of a highly diluted solution of local anesthesia into skin and subcutaneous tissues) is a technique for delivering anesthesia for superficial surgical procedures. TLA obviates the need for general anesthesia or intravenous sedation in most cases. Pain control and TLA-related complications are key factors in determining the success of TLA.
\end{abstract}

OBJECTIVE: To conduct a systematic review of the English medical literature's data regarding pain control and TLA-related complications in TLA surgical cases to determine its efficacy and safety

EVIDENCE REVIEW: The review was performed in accordance with the Preferred Reporting Items for Systematic Reviews and Meta-Analyses guidelines (PRISMA). Searches of both the MEDLINE and EMBASE databases were performed. Articles using 10-point quantitative scales were included in the pain analysis. Complications were tabulated from cohort studies, case series, and case reports. A total of 184 articles cotaining reports of 71,483 surgical procedures met inclusion criteria, including 43 with pain outcomes and 141 reporting complications.

FINDINGS: Liposuction procedures were associated with relatively low degree of both intraoperative pain $(10$-point visual analog scale $1.1 \pm 2.1)$ and post-operative pain $(0.53 \pm 0.44)$ and the fewest complications (1.2\%). The highest intra-operative and post-operative pain was reported in facial/cleft-lip surgery (3.7 and 3.99, respectively), while mastectomy was associated with highest post-operative complication risk (20.8\%). There were 8 reported cases of death 
unlikely related to TLA: pulmonary embolus (4 cases), complications related to concurrent general anesthesia ( 2 cases), hemorrhage, and visceral perforation. There were 5 reported cases of death related to TLA (lidocaine/bupivacaine toxicity in 4 cases and one case of fluid overload) during its development when optimal dose and volume parameters were being established. There have been no TLA-associated deaths reported in the 33,429 cases published since 2003.

CONCLUSIONS AND RELEVANCE This systematic review demonstrates TLA to be a safe and effective anesthetic approach. Its low-cost and rapid patient recovery warrant further studies of cost-reduction and patient satisfaction. Expanded education of TLA techniques in surgical and anesthesia training programs may be considered to broaden patient access to this anesthetic modality for cutaneous and subcutaneous surgical procedures. 
medRxiv preprint doi: https://doi.org/10.1101/2020.08.10.20170720; this version posted August 14, 2020. The copyright holder for this preprint (which was not certified by peer review) is the author/funder, who has granted medRxiv a license to display the preprint in perpetuity.

All rights reserved. No reuse allowed without permission.

\section{Key Points}

Question: Is TLA an effective and safe local anesthetic technique for pain management during surgical procedures?

Findings In this review of 157 publications, TLA was a safe and effective anesthetic approach.

The least pain and fewest complications were in liposuction procedures. The highest postoperative complication risk was with mastectomy. Though five TLA-related deaths were reported in early liposuction cases, there have been no deaths in the 33,429 TLA cases published since 2003.

Meaning TLA is an effective and safe anesthetic technique which enables cutaneous and subcutaneous surgery to be performed in office-based settings with high safety and low cost. 
medRxiv preprint doi: https://doi.org/10.1101/2020.08.10.20170720; this version posted August 14, 2020. The copyright holder for this preprint (which was not certified by peer review) is the author/funder, who has granted medRxiv a license to display the preprint in perpetuity.

All rights reserved. No reuse allowed without permission.

\section{INTRODUCTION}

Tumescent local anesthesia (TLA) is an anesthetic technique which uses the infiltration of a very dilute local anesthetic (usually lidocaine) into tissue to achieve an anesthetic effect while minimizing side effects due to the anesthetic components. ${ }^{1-5}$ The makeup of TLA has historically consisted of a diluted local anesthetic combined with epinephrine and sodium bicarbonate, for example, 500-1000 mg lidocaine and $1 \mathrm{mg}$ epinephrine solution and 12.5 meq sodium bicarbonate solution with $1000 \mathrm{ml}$ normal saline ${ }^{2}$ Since Jeffrey Klein first introduced this method to the field of dermatologic anesthetic surgery in the 1980s, ${ }^{1,2}$ TLA has gained widespread interest within the medical community. ${ }^{4,5}$ Its application has since expanded to include breast reconstruction, hand, and burn surgeries among others due to its many benefits. ${ }^{4-12}$ Potential advantages of utilizing TLA include: 1) low reported incidence of post-operative complications, ${ }^{9}$ 2) reduced blood loss due to epinephrine-induced vasoconstriction and hydrostatic compression from the tumescent effect, ${ }^{2,13}$

3) low infection rates due to potential bacteriostatic effects of lidocaine and common use of outpatient surgical environments, ${ }^{14,15}$ 4) pain relief from the alkaline component of the TLA solution, ${ }^{13,16-19} 5$ ) relatively long lasting anesthetic effects, ${ }^{20-22}$ and 6) lower costs when compared to general anesthesia.

Over the last three decades, the specific local anesthetic agents used have been expanded from classical lidocaine to other amino amide or amino ester anesthetics, including articaine, bupivacaine, etidocaine, mepivacaine and prilocaine amide class, as well as chloroprocaine, procaine, and tetracaine ester class anesthetics. ${ }^{4,5}$ Of note, lidocaine is currently still used in the vast majority of TLA applications., ${ }^{4,5}$ In current liposuction procedures, lidocaine (with epinephrine) in doses $35-55 \mathrm{mg} / \mathrm{kg}$ is routinely used with an excellent safety record. ${ }^{2,5,23}$ Klein et al, 2016 notes that the liposuction procedure itself may remove a portion of the TLA lidocaine 
during suction, before the drug can be absorbed into the systemic circulation. ${ }^{24}$ Therefore, the optimal dose of TLA lidocaine for procedures other than liposuction may be lower. Recent literature suggests that the maximum safe dosages of TLA lidocaine may be $28 \mathrm{mg} / \mathrm{kg}$ for procedures without liposuction, ${ }^{5,24}$ and $45 \mathrm{mg} / \mathrm{kg}$ for procedures with liposuction. ${ }^{24}$

A number of review articles have been written on TLA focusing on technique. ${ }^{4,5,8-10}$ However, none have systematically summarized the available data regarding pain control and postoperative complications - two key factors in determining the success of an anesthesia protocol. In the current work, the published English literature reporting pain outcomes and complications has been summarized and analyzed, including studies that directly compare TLA to general anesthesia (GA), in order to provide physicians with a comprehensive, up-to-date summary of the current uses, safety, and efficacy of TLA as compared to GA.

\section{METHODS}

\section{Search strategy}

A systematic review was performed in accordance with the Preferred Reporting Items for Systematic Reviews and Meta-Analyses guidelines [PRISMA citation] to evaluate all available data published in English on pain and procedure-related complications relating to TLA use in surgical procedures. Searches of both the MEDLINE and EMBASE databases were performed on June 1, 2017 and August 20, 2019. The following search terms were used for study extraction: "xylocaine tumescent", "lidocaine tumescent", "xylocaine dilution", "lidocaine dilution" "xylocaine dilutional", "lidocaine dilutional”, "tumescent", "tumescence anesthesia", "tumescence local”. 
medRxiv preprint doi: https://doi.org/10.1101/2020.08.10.20170720; this version posted August 14, 2020. The copyright holder for this preprint (which was not certified by peer review) is the author/funder, who has granted medRxiv a license to display the preprint in perpetuity.

All rights reserved. No reuse allowed without permission.

\section{Selection criteria}

Only articles where procedures were completed using TLA were included. Post and peri-operative complications, regardless of whether they were attributed to TLA, were tabulated from cohort studies, case series, and case reports. Articles that reported pain data using a quantitative scale (VAS, visual analog scale) were included in the pain analysis.

\section{Study selection and data extraction}

All articles yielded by the aforementioned search were screened independently for eligibility by two researchers. Reference lists from articles were also reviewed to identify additional articles that were missed in the initial screen. Studies containing primary data regarding pain or complications were included. The following post-operative complication parameters were extracted from each article: presence of hematoma, seroma, infection, severe scarring, nerve injury, skin and/or fat necrosis at the procedure site, wound dehiscence, and any other adverse post-operative sequelae. Primary intra-operative and post-operative pain data that recorded pain based on the visual analog scale (VAS) or an equivalent (0-10 point scoring system with 0 being no pain and 10 being the worst possible pain) were included in the pain analysis.

\section{Statistical analysis}

Statistical analyses were conducted using SPSS statistical software. Complication outcomes were tabulated as the number of total incidents in each parameter, and the percentage of patients experiencing each parameter. Pain data were summarized as weighted means and standard deviations of the reported VAS scores for each procedure type. Pain calculations were weighted according to number of patients in each procedure category. 


\section{RESULTS}

The searches of MEDLINE and EMBASE yielded 3,336 articles (Figure 1). Duplicates and nonrelevant papers were removed, leaving 737 articles to be screened. Ultimately, 553 articles were excluded because they failed to meet selection criteria or did not contain the required information as indicated in Figure 1. Of the remaining 157 articles, 32 relating to pain outcomes and 125 relating to post-operative complication outcomes were included for analysis. The numbers of published works in liposuction, cutaneous surgery, plastic surgery, breast procedures, and hand surgery are reported in Figure 2.

\section{Intra-operative Pain Outcomes (Table 1)}

To quantify the amount of pain during TLA procedures, intra-operative pain data from 15 published works was analyzed (see Table 1). All pain data were reported using the visual analog scale (VAS) system or a comparable quantitative pain scale. Pain scores were reported after injection of TLA at various time points during execution of vascular, plastic or hand surgical procedures (Table 1).

Dermatologic procedures and liposuction procedures were associated with the lowest degree of intra-operative pain with a mean of 0.9 for dermatologic procedures (Standard deviation, SD 0.96), and 1.1 (SD 2.1) for liposuction procedures. Weighted mean pain scores during facial/cleft-lip surgery were 3.7 (original SD data not provided). Varicose vein treatments were associated with relatively low pain: 2.16 (SD 1.07) for endovenous laser treatment (EVLT/ELT) and 2.43 (SD 0.80) for phlebectomy. 
medRxiv preprint doi: https://doi.org/10.1101/2020.08.10.20170720; this version posted August 14, 2020. The copyright holder for this preprint (which was not certified by peer review) is the author/funder, who has granted medRxiv a license to display the preprint in perpetuity.

All rights reserved. No reuse allowed without permission.

Post-operative Pain Outcomes (Table 2)

Data on post-operative pain (within the first post-operative day) was gathered from 28 published works (Table 2). The lowest post-operative pain scores were reported for liposuction procedures 0.53 (SD 0.44), followed by radiofrequency ablation therapy was $0.65(0.10)$ for treatment of varicose veins. The weighted mean VAS score for other vascular surgery were medium, with phlebectomy and endovenous laser therapy procedures 1.73 (SD 0.52) and 2.44 (SD 1.35), respectively. The weighted mean VAS score were 2.6 (SD not provided) for breast procedures, 2.77 (SD 0.43) for hand surgery, then facial/cleft-lip procedures 3.99 (SD 0.49).

\section{Complications reported in TLA cases (Table 3)}

Table 3 summarizes the post-operative complications based on 38,430 cases using TLA. Liposuction was by far the most commonly reported procedure with 27,767 cases. Endovenous laser ablation and mastectomy were also well-reported at 3,026 and 2,602 cases, respectively. The large majority of reported procedures including liposuction and endovenous laser ablation had complication risks below 5\%. Phlebotomy, non-liposuction body reconstruction/ recontouring, breast reduction, hand surgery and inguinal hernia repair had post-operative complication rates in the $5-10 \%$ range $(2.2,7.9,6.2,9.5$, and $5.4 \%$, respectively). Only mastectomy, hyperhidrosis and facial surgery had higher complication risks $(20.8,11.4$, and $10.9 \%$, respectively). In terms of specific complications experienced, only two occurred in more than 5\% of cases: hematoma which occurred in $7.6 \%$ of 430 hyperhidrosis cases, and $5.4 \%$ of 612 inguinal hernia cases, and skin or fat necrosis which occurred in $13.2 \%$ of the 2,602 mastectomy cases reported. 


\section{Reported Cases of Death Associated with TLA Use}

Thirteen cases of death have been reported in TLA procedures, all associated with liposuction performed before 2003. Rao and colleagues ${ }^{25}$ reported 5 deaths associated with 48,527 tumescent liposuction procedures conducted between 1993-1998. Kaminer and colleague reported 4 deaths in tumescent liposuction cases conducted over 18 years from 1983-2001, but did not report total number of procedures performed. ${ }^{26}$ Lehnhardt et al reported 4 TLA-related deaths among 72 severe complications reported in a survery study (2,275 respondents) regarding liposuction procedures in Germany between $1998-2002 .{ }^{27}$ The causes of death in these 13 cases were TLArelated in 5 cases (lidocaine/bupivacaine toxicity in 4 cases, and fluid overload in a single case) and likely TLA-unrelated in 8 cases [pulmonary embolus (4 cases), concurrent general anesthetic complications ( 2 cases), hemorrhage (1 case), visceral perforation (1 case)]. There have been no deaths in the 33,429 TLA cases published in 146 studies since 2003. ${ }^{30-32}$ These above studies collectively indicate that TLA is a safe procedure. 
medRxiv preprint doi: https://doi.org/10.1101/2020.08.10.20170720; this version posted August 14, 2020. The copyright holder for this preprint (which was not certified by peer review) is the author/funder, who has granted medRxiv a license to display the preprint in perpetuity.

All rights reserved. No reuse allowed without permission.

\section{DISCUSSION}

The findings herein reflect a body of evidence that TLA has an excellent safety profile and effectively controls intraoperative and post-operative pain, with less complications. Mean pain scores ranged from $0.53-3.99$ on a 0-10 analog scale indicating minimal pain experienced intraoperatively and on post-operative day 1 (see Table 1). In addition, TLA may be safer than general anesthesia. When liposuction was introduced into clinical practice by Giorgio Fischer in the $1970 \mathrm{~s},{ }^{31,33}$ serious complications were common and the greatest risks were associated with general anesthesia. ${ }^{31}$ Application of the TLA was an important technical breakthrough as it can avoid the most severe complications encountered in the early years of liposuction with general anesthesia. ${ }^{1,2}$ Though five TLA-related deaths have been reported, all were in liposuction cases performed prior to 2003 when maximal lidocaine doses and fluid volumes were still being established. There have been no deaths in the 33,429 TLA cases published since 2003.

In the past three decades, TLA anesthesia has become a standard anesthetic approach with good pain management and low complication risks. ${ }^{1-5,24}$ The technical advancement and standardization of TLA has paved the way for expansion of its application beyond liposuction to various other minimally invasive surgical procedures involving cutaneous and subcutaneous tissues (e.g. breast, vascular, hand, hernia, and cleft-palate surgery). ${ }^{4,5,24}$ In these procedures, TLA has shown advantages not only in efficacy and safety, but also in terms of cost reduction in its application for office-based surgical procedures.

The results herein report a subset of procedures in which TLA had a relatively higher complication risk, i.e. mastectomy (20.8\%), hyperhidrosis surgery (11.4\%) and facial surgery 
medRxiv preprint doi: https://doi.org/10.1101/2020.08.10.20170720; this version posted August 14, 2020. The copyright holder for this preprint (which was not certified by peer review) is the author/funder, who has granted medRxiv a license to display the preprint in perpetuity.

All rights reserved. No reuse allowed without permission.

(10.9\%). Comparable data regarding complications in similar surgeries performed under general anesthesia is only available for breast surgery. Risk of flap necrosis in breast reconstruction has been reported to be $14 \%$ with general anesthesia which is comparable to the $12.8 \%$ risk reported herein with TLA in a retrospective study of total 730 cases with breast reconstructions. ${ }^{11}$ Similarly, risk of skin necrosis in mastectomy appears to be comparable in general anesthesia vs. TMA cases (7\% vs $10 \%$, respectively) in a retrospective study which included 601 nontumescent and 890 tumescent cases. ${ }^{9}$ However, two smaller studies containing 100 and 332 tumescent patients, respectively, reported the risk of skin necrosis in mastectomy to be $34 \%$ and $15 \%$ higher with tumescent anesthesia than general anesthesia, respectively. ${ }^{34,35}$ Using lower dose of lidocaine (not exceeding $28 \mathrm{mg} / \mathrm{kg}$ ) in the TLA might be helpful. In their daily clinical practice, many surgeons may, however, associate TLA with deep sedation or general anesthesia in some procedures, i.e. abdominoplasty, mastectomy, or large volume liposuction. In addition to the above mentioned risk or side effects, the total volume of the infiltrated liquid during the TLA procedure should be carefully regulated, as the fluid overload may result in heart failure.

Long-acting local anesthetics such as liposomal bupivicaine injected locally at the end of joint replacement surgery have been recently associated with outstanding pain control and no elevation in complications. These formulations contain much higher concentrations of bupivicaine and epinephrine than TLA but appear to be largely devoid of complications. ${ }^{36}$ Additional approaches for optimization of pain management during the TLA procedures include 1) slowing rate of infiltration, 2) vibrating the skin, 3) warming TLA solution, and 4) cooling the local skin of the TLA procedure, ${ }^{4,37}$ as well as 5) using thinner needles, and 6) adjusting needle insertion angles. ${ }^{38}$ Zelickson and colleagues reported the parallel and minimal needle-insertion technique to 
the skin into the superficial dermis with $0.5 \%$ lidocaine containing 1:200,000 epinephrine buffered 1:10 with $8.4 \%$ sodium bicarbonate achieved a painless injection of local anesthetic. ${ }^{38}$

The cost for office-based surgery with TLA is much lower than the same surgical procedures conducted as inpatients with general anesthesia. ${ }^{39}$ Broader application of TLA would therefore reduce costs and possibly reduce hospital-based iatrogenic morbidity, i.e. hospital acquired infection. However, given the inherent limitation of TLA application to cutaneous and subcutaneous tissues where local infiltration of anesthetics can be easily achieved, TLA is not practical for intrathoracic, abdominal, or neural surgeries, or for prolonged or highly complex superficial surgeries. 
medRxiv preprint doi: https://doi.org/10.1101/2020.08.10.20170720; this version posted August 14, 2020. The copyright holder for this preprint (which was not certified by peer review) is the author/funder, who has granted medRxiv a license to display the preprint in perpetuity.

All rights reserved. No reuse allowed without permission.

\section{CONCLUSIONS}

The data herein indicate that TLA has an outstanding record of safety and efficacy across a wide range of surgical procedures. TLA safety appears to be equivalent or superior to general anesthesia with minimal patient discomfort/complications and very low risk of death. Its low-cost and rapid patient recovery warrant further studies of cost-reduction and patient satisfaction. Expanded education of TLA techniques in surgical and anesthesia training programs should be undertaken in order to broaden patient access to this safe and effective anesthetic modality for cutaneous and subcutaneous surgical procedures. 
medRxiv preprint doi: https://doi.org/10.1101/2020.08.10.20170720; this version posted August 14, 2020. The copyright holder for this preprint (which was not certified by peer review) is the author/funder, who has granted medRxiv a license to display the preprint in perpetuity.

All rights reserved. No reuse allowed without permission.

Figure 1. Flow chart summary of search process

\section{Methodology for Literature Search}

Databases: PubMed, Embase, Cochrane

Filters: “English", “Full text”, "Human”

Search Terms Used:

Xylocaine dilution

Xylocaine dilutional

Tumescent anesthesia

Tumescen*

Xylocaine tumescent

Tumescence anesthesia

Tumescence local

\section{PRISMA}

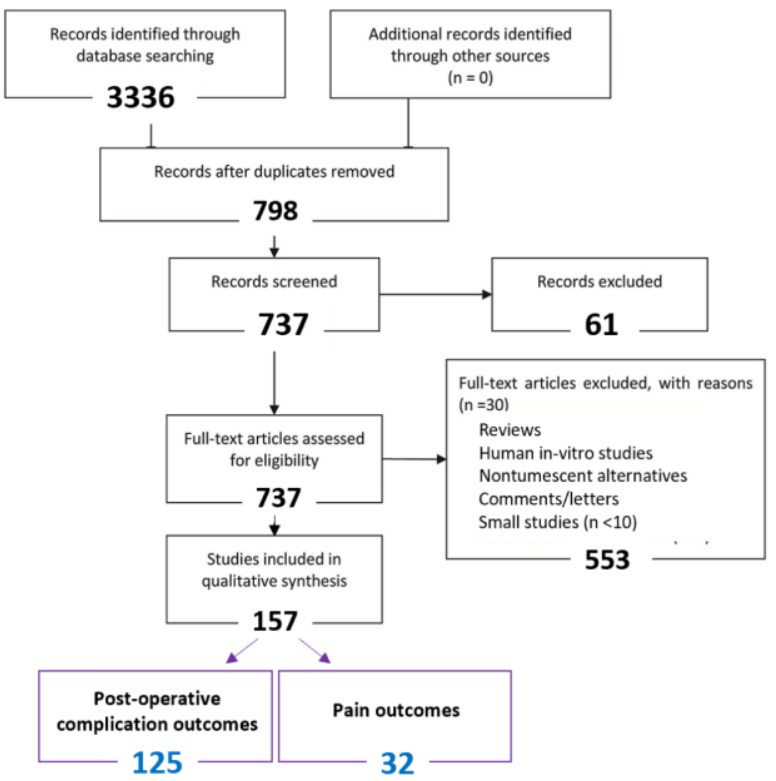


medRxiv preprint doi: https://doi.org/10.1101/2020.08.10.20170720; this version posted August 14, 2020. The copyright holder for this preprint (which was not certified by peer review) is the author/funder, who has granted medRxiv a license to display the preprint in perpetuity.

All rights reserved. No reuse allowed without permission.

Figure 2. Number of TLA publications by procedure type

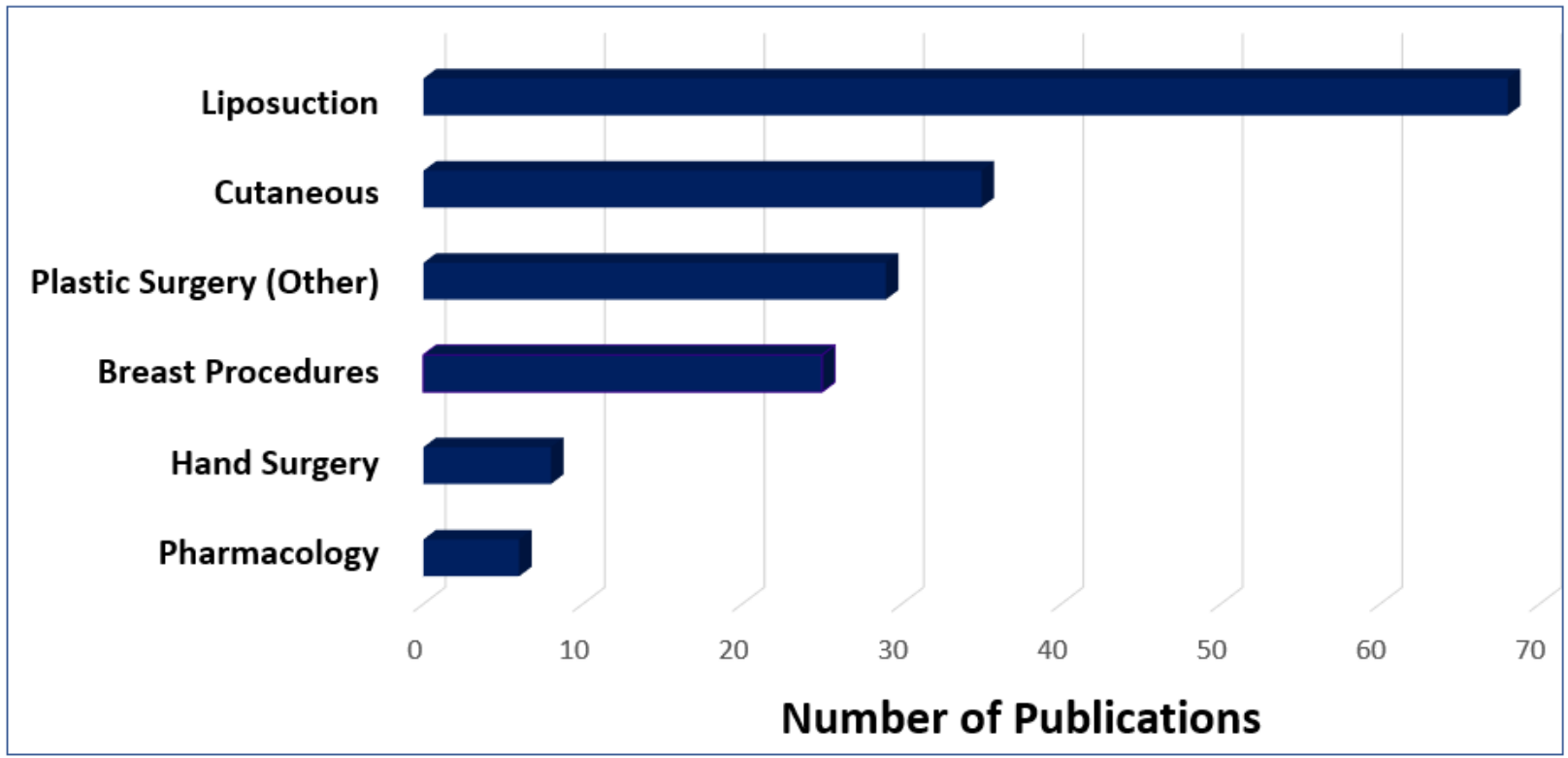


Table 1. INTRA-OPERATIVE PAIN DATA (VAS, 0-10)

\begin{tabular}{|c|c|c|c|c|c|}
\hline $\begin{array}{l}\text { Disease/ } \\
\text { Surgery }\end{array}$ & Procedure & $\begin{array}{l}\# \\
\text { Patients } \\
\text { (N) }\end{array}$ & $\begin{array}{l}\text { Weighted } \\
\text { Mean }\end{array}$ & $\begin{array}{l}\text { Weighted } \\
\text { SD }\end{array}$ & Publications \\
\hline \multirow[t]{2}{*}{$\begin{array}{l}\text { Vascular } \\
\text { Surgery }\end{array}$} & $\begin{array}{l}\text { Endovenous Laser } \\
\text { Therapy }\end{array}$ & 996 & 2.16 & 1.07 & $\begin{array}{l}7 \text { studies: } \\
\text { Kutas et al }{ }^{40} 2015 ; \\
\text { Dzieciuchowicz et al }{ }^{41} 2010 ; \\
\text { Gunes et al, }{ }^{42} 2015 ; \\
\text { Dumantepe et al, }{ }^{43} 2015 ; \\
\text { Abud et al, }{ }^{44} 2014 ; \\
\text { Pronk et al, }{ }^{45} 2010 ; ; \\
\text { Hamel-Desnos et al, }{ }^{49} 2015 ; \\
\text { Memetoglu, et al } 2010\end{array}$ \\
\hline & Phlebectomy & 324 & 2.43 & 0.80 & $\begin{array}{l}\text { studies: } \\
\text { Krasznai et al, }{ }^{56} 2015 ; \\
\text { Smith et al, }{ }^{57} 1998 ; \\
\text { Creton et al, }{ }^{58} 2012\end{array}$ \\
\hline \multirow{2}{*}{$\begin{array}{l}\text { Plastic } \\
\text { Surgery }\end{array}$} & $\begin{array}{l}\text { Liposuction/ } \\
\text { Related Procedures }\end{array}$ & 26 & 1.1 & 2.1 & $\begin{array}{l}\text { study: } \\
\text { Augustin et al, }{ }^{60} 2010 \text {; }\end{array}$ \\
\hline & $\begin{array}{l}\text { Facial Surgery/ } \\
\text { Cleft Lip Surgery }\end{array}$ & 82 & 3.7 & $\mathrm{n} / \mathrm{a} *$ & $\begin{array}{l}1 \text { study: } \\
\text { Bertelsen et al, }{ }^{62} 2011 \\
\text { *Study gives confidence interval, could } \\
\text { not calculate SD } \\
\end{array}$ \\
\hline Dermatology & $\begin{array}{l}\text { Ablative laser/ } \\
\text { Electrochemotherapy }\end{array}$ & 12 & 0.9 & 0.96 & $\begin{array}{l}2 \text { studies: } \\
\text { Kessels et al, } 2012 \\
\text { Kendler et al } 2013\end{array}$ \\
\hline $\begin{array}{l}\text { Other } \\
\text { Surgery }\end{array}$ & Hand Surgery & 40 & 1.2 & $\mathrm{n} / \mathrm{a}^{*}$ & $\begin{array}{l}1 \text { study: } \\
\text { Ceran et al, }{ }^{64} 2015 \\
\text { *Study gives confidence interval, could } \\
\text { not calculate SD } \\
\end{array}$ \\
\hline
\end{tabular}


Table 2. POST-OPERATIVE DAY ONE PAIN DATA (VAS, 0-10)

\begin{tabular}{|c|c|c|c|c|c|}
\hline $\begin{array}{l}\text { Disease/ } \\
\text { Surgery }\end{array}$ & Procedure & $\begin{array}{l}\text { \# Patients } \\
\text { (N) }\end{array}$ & $\begin{array}{l}\text { Weighted } \\
\text { Mean }\end{array}$ & $\begin{array}{l}\text { Weighted } \\
\text { SD } \\
\end{array}$ & Publications \\
\hline \multirow[t]{3}{*}{$\begin{array}{l}\text { Vascular } \\
\text { Surgery }\end{array}$} & $\begin{array}{l}\text { Endovenous } \\
\text { Laser Therapy }\end{array}$ & 1466 & 2.44 & 1.35 & $\begin{array}{l}13 \text { studies: } \\
\text { Gunes et al, }{ }^{42} 2015 ; \\
\text { Dumantepe et al, }{ }^{43} 2015 ; \\
\text { Abud et al, }{ }^{44} 2014 ; \\
\text { Pronk et al, }{ }^{45} 2010 ; \\
\left.\text { Jibiki et al, }{ }^{47} 2016\right) ; \\
\text { Memetoglu et al, }{ }^{48} 2010 ; \\
\text { Hamel-Desnos et al, }{ }^{49} 2015 ; \\
\text { Pannier et al, }{ }^{50} 2011 ; \\
\text { Van Zandvoort et al, }{ }^{51} 2016 ; \\
\text { Wallace et al, }{ }^{52} 2017 ; \\
\text { Rasmussen et al, }{ }^{53} 2007 \\
\text { Nandhra et al, } 2018 \\
\text { Wahbi et al, } 2017\end{array}$ \\
\hline & $\begin{array}{l}\text { Radiofrequency } \\
\text { Ablation }\end{array}$ & 242 & 0.65 & 0.10 & $\begin{array}{l}2 \text { studies: } \\
\text { Proebstle et al, }{ }^{54} 2008 ; \\
\text { Kendler et al, }{ }^{55} 2013\end{array}$ \\
\hline & Phlebectomy & 324 & 1.73 & 0.52 & $\begin{array}{l}3 \text { studies: } \\
\text { Krasznai et al, }{ }^{56} 2015 ; \\
\text { Smith et al, }{ }^{57} 1998 ; \\
\text { Creton et al, }{ }^{58} 2012 \\
\end{array}$ \\
\hline \multirow[t]{3}{*}{$\begin{array}{l}\text { Plastic } \\
\text { Surgery }\end{array}$} & $\begin{array}{l}\text { Liposuction/ } \\
\text { Related } \\
\text { Procedures }\end{array}$ & 206 & 0.53 & 0.44 & $\begin{array}{l}3 \text { studies: } \\
\text { Schmeller et al, }{ }^{59} 2012 \text {; } \\
\text { Augustin et al, }{ }^{0} 2010 ; \\
\text { Danilla et al, } 2013\end{array}$ \\
\hline & $\begin{array}{l}\text { Breast } \\
\text { Procedures }\end{array}$ & 20 & 2.6 & $\mathrm{n} / \mathrm{a}$ & $\begin{array}{l}2 \text { studies: } \\
\text { Khater et al, }{ }^{22} 2017\end{array}$ \\
\hline & $\begin{array}{l}\text { Facial Surgery/ } \\
\text { Cleft Lip } \\
\text { Surgery }\end{array}$ & 112 & 3.99 & 0.49 & $\begin{array}{l}1 \text { study: } \\
\text { Bertelsen et al, }{ }^{62} 2011 \\
\text { Kim et al, } 2017\end{array}$ \\
\hline Dermatology & $\begin{array}{l}\text { Ablative laser/ } \\
\text { Electrochemoth } \\
\text { erapy }\end{array}$ & 12 & 1.27 & 0.20 & $\begin{array}{l}2 \text { studies: } \\
\text { Kessels et al, } 2012 \\
\text { Kendler et al } 2013\end{array}$ \\
\hline $\begin{array}{l}\text { Other } \\
\text { Surgery }\end{array}$ & Hand Surgery & 52 & 2.77 & 0.43 & $\begin{array}{l}2 \text { studies: } \\
\text { Prasetyono et al, }{ }^{63} 2016 \text {; } \\
\text { Ceran et al, }{ }^{64} 2015\end{array}$ \\
\hline
\end{tabular}


Table 3. Complications of Tumescent Local Anesthesia

\begin{tabular}{|c|c|c|c|c|c|c|c|c|c|c|c|}
\hline & Procedure & $\begin{array}{l}\text { \# Patients((\% } \\
\text { complications) }\end{array}$ & $\begin{array}{l}\text { Hematoma } \\
(\%)\end{array}$ & $\begin{array}{l}\text { Seroma } \\
(\%)\end{array}$ & $\begin{array}{l}\text { Infection } \\
(\%)\end{array}$ & $\begin{array}{l}\text { Bleeding } \\
(\%)\end{array}$ & $\begin{array}{l}\text { Severe } \\
\text { Scarring } \\
(\%)\end{array}$ & $\begin{array}{l}\text { Nerve } \\
\text { injury } \\
\text { (\%) }\end{array}$ & $\begin{array}{l}\text { Skin/ Fat } \\
\text { necrosis } \\
\text { (\%) }\end{array}$ & $\begin{array}{l}\text { Wound } \\
\text { Dehiscence } \\
(\%) \\
\end{array}$ & Others (\# of patients) \\
\hline \multirow[t]{5}{*}{ Dermatology } & Dermabrasion & $34(2.9)$ & - & - & - & - & - & - & - & - & $\begin{array}{l}1 \text { contact dermatitis } \\
\text { Goodman et al, }{ }^{65} 1994\end{array}$ \\
\hline & $\begin{array}{l}\text { Hyperhidrosis } \\
\text { Surgery }\end{array}$ & $430(11.4)$ & $33(7.6)$ & - & $2(0.5)$ & - & $5(1.2)$ & - & $8(1.9)$ & - & $\begin{array}{l}1 \text { contact dermatitis } \\
\text { Budamakuntla et al, }{ }^{6} 2017\end{array}$ \\
\hline & $\begin{array}{l}\text { Photodynamic } \\
\text { surgery }\end{array}$ & $8(-)$ & - & - & - & - & - & - & - & - & \\
\hline & $\begin{array}{l}\text { Dermatologic } \\
\text { surgery* }\end{array}$ & $467(3.6)$ & $4(0.5)$ & - & $4(1.1)$ & $2(0.5)$ & - & - & $4(1.1)$ & $3(0.8)$ & \\
\hline & Other $^{*}$ & $457(7.9)$ & $2(0.4)$ & $18(3.9)$ & $14(3.1)$ & - & - & - & - & $2(0.4)$ & \\
\hline \multirow[t]{4}{*}{$\begin{array}{l}\text { Vascular \& } \\
\text { Endovascular } \\
\text { Surgery }\end{array}$} & $\begin{array}{l}\text { Endovenous } \\
\text { Laser Therapy }\end{array}$ & $3026(4.0)$ & $32(1.1)$ & - & $6(0.2)$ & - & - & $60(2.0)$ & - & - & $\begin{array}{l}1 \text { granuloma annulare, Cartee, }{ }^{67} \\
2015 ; \\
3 \text { arterio-venous fistula, } \\
\text { Theivacumar, }{ }^{68} 2009 ; \\
17 \text { contact dermatitis, Hirokawa, } \\
692014 ; \\
1 \text { arterial false aneurysm, Ostler, } \\
702015\end{array}$ \\
\hline & $\begin{array}{l}\text { Radiofrequency } \\
\text { Ablation } \\
\end{array}$ & $607(1.8)$ & $9(1.5)$ & - & - & - & - & $2(0.3)$ & - & - & \\
\hline & Sclerotherapy & $25(-)$ & - & - & - & - & - & - & - & - & \\
\hline & Phlebectomy & $451(2.2)$ & $7(1.6)$ & $1(0.2)$ & - & - & - & - & - & - & $\begin{array}{l}\text { contact dermatitis, Spornraft- } \\
\text { Ragaller, }{ }^{71} 2009 ; \\
1 \text { necrotizing fasciitis, Hubmer, }{ }^{72} \\
2004\end{array}$ \\
\hline \multirow[t]{9}{*}{$\begin{array}{l}\text { Plastic } \\
\text { Surgery }\end{array}$} & $\begin{array}{l}\text { Liposuction/ } \\
\text { Related } \\
\text { Procedures }\end{array}$ & $27767(1.2)$ & $48(0.2)$ & $125(0.5)$ & $80(0.3)$ & $1\left(3 \times 10^{-3}\right)$ & $19(0.07)$ & $8(0.03)$ & $29(0.1)$ & $14(0.05)$ & $\begin{array}{l}1 \text { acute pulmonary edema, } \\
\text { Wollina, }{ }^{73} 2014 ; \\
1 \text { pneumothorax, Hake, }{ }^{74} 2004 ; \\
4 \text { arrhythmic events, Hanke, }{ }^{28} \\
1995 ; \\
1 \text { Group A strep fasciitis, Beeson, } \\
752001 ; \\
1 \text { pulmonary edema, Gilliland, }{ }^{76} \\
1997\end{array}$ \\
\hline & $\begin{array}{l}\text { Autologous Fat } \\
\text { Transfer }\end{array}$ & $35(-)$ & - & - & - & - & - & - & - & - & \\
\hline & $\begin{array}{l}\text { Facial } \\
\text { Procedures }\end{array}$ & $402(10.9)$ & $8(2.0)$ & $6(1.5)$ & $6(1.5)$ & $11(2.7)$ & $2(0.5)$ & $1(0.2)$ & - & $10(2.5)$ & \\
\hline & $\begin{array}{l}\text { Body } \\
\text { Procedures* }\end{array}$ & $343(7.9)$ & $2(0.6)$ & $20(5.8)$ & - & - & - & - & - & $5(1.5)$ & \\
\hline & Mastectomy & $2602(20.8)$ & $54(2.1)$ & $51(2.0)$ & $93(3.6)$ & - & - & - & $343(13.2)$ & - & \\
\hline & $\begin{array}{l}\text { Breast } \\
\text { Augmentation }\end{array}$ & $260(0.8)$ & $2(0.8)$ & - & - & - & - & - & - & - & \\
\hline & $\begin{array}{l}\text { Breast } \\
\text { Reduction } \\
\end{array}$ & $260(6.2)$ & $3(1.2)$ & - & - & - & - & - & $13(5)$ & - & \\
\hline & Hand & $21(9.5)$ & $1(4.8)$ & - & - & - & - & - & - & - & $\begin{array}{l}1 \text { hypertrophic scar, Prasetyono, } \\
772015\end{array}$ \\
\hline & $\begin{array}{l}\text { Inguinal hernia } \\
\text { repair }\end{array}$ & $612(5.4)$ & $14(2.3)$ & $14(2.3)$ & - & - & - & - & - & - & $\begin{array}{l}3 \text { scrotal swelling, } 2 \text { urinary } \\
\text { problems, Chyung, } 102014\end{array}$ \\
\hline
\end{tabular}




\begin{tabular}{|c|c|c|}
\hline DERM/ Dermatologic surgery* & DERM/Other* & Body Procedures* \\
\hline $\begin{array}{l}\text { - } \quad \text { Shave excision } \\
\text { - } \quad \text { Congenital melanocytic nevi } \\
\text { treatment } \\
\text { - } \quad \text { Forehead flap procedure } \\
\text { - } \quad \text { Skin defect reconstruction }\end{array}$ & $\begin{array}{ll}\text { - } & \text { Ablative laser treatment } \\
\text { - } & \text { Electrochemotherapy } \\
\text { - } & \text { Lymph node } \\
\text { biopsy/dissection }\end{array}$ & $\begin{array}{ll}\text { - } & \text { Pectoral reshaping/ fat grafting/ } \\
& \text { removal } \\
\text { - } & \text { Fat/ panniculectomy surgery } \\
\text { - } & \text { Buttock lift/ polypropylene strips } \\
\text { - } & \text { Gluteoplasty } \\
\text { - } & \text { Lipoma excision } \\
\text { - } & \text { Pilonidal cyst } \\
\text { - } & \text { Craniofacial surgery }\end{array}$ \\
\hline
\end{tabular}

Case Studies - Highlighted Uses of tumescent anesthesia

- Port Wine Stain treatment

- Cutaneous Schwannoma treatment

- "Witch's Chin," and Nasal Deformities Excision and Reconstruction

- Hemi-hyperplasia Multiple Lipomatosis Syndrome treatment

- Severe post-burn contracture release/skin graft harvest

- Partial Hemi-facial Hypertrophy treatment 
medRxiv preprint doi: https://doi.org/10.1101/2020.08.10.20170720; this version posted August 14, 2020. The copyright holder for this preprint (which was not certified by peer review) is the author/funder, who has granted medRxiv a license to display the preprint in perpetuity. All rights reserved. No reuse allowed without permission.

\section{REFERENCES}

1. Klein JA. Anesthesia for liposuction in dermatologic surgery. The Journal of dermatologic surgery and oncology. Oct 1988;14(10):1124-1132.

2. Klein JA. Tumescent technique for regional anesthesia permits lidocaine doses of $35 \mathrm{mg} / \mathrm{kg}$ for liposuction. The Journal of dermatologic surgery and oncology. Mar 1990;16(3):248263.

3. Klein JA. Tumescent technique chronicles. Local anesthesia, liposuction, and beyond. Dermatologic surgery : official publication for American Society for Dermatologic Surgery [et al.]. May 1995;21(5):449-457.

4. Kouba DJ, LoPiccolo MC, Alam M, et al. Guidelines for the use of local anesthesia in office-based dermatologic surgery. Journal of the American Academy of Dermatology. Jun 2016;74(6):1201-1219.

5. Holt NF. Tumescent anaesthesia: its applications and well tolerated use in the out-ofoperating room setting. Curr Opin Anaesthesiol. May 152017.

6. Palmieri B, Benuzzi G. Tumescent anaesthesia in plastic surgery. Rivista Italiana di Chirurgia Plastica. 2003;35(1-2):51-55.

7. Gutowski KA. Tumescent analgesia in plastic surgery. Plastic and reconstructive surgery. Oct 2014;134(4 Suppl 2):50s-57s.

8. Lalonde D, Martin A. Tumescent local anesthesia for hand surgery: improved results, cost effectiveness, and wide-awake patient satisfaction. Archives of plastic surgery. Jul 2014;41(4):312-316.

9. Khavanin N, Fine NA, Bethke KP, et al. Tumescent technique does not increase the risk of complication following mastectomy with immediate reconstruction. Annals of surgical oncology. 2014;21(2):384-388.

10. Chyung JW, Shin DG, Kwon Y, et al. Tumescent local anesthetic technique for inguinal hernia repairs. Annals of surgical treatment and research. Dec 2014;87(6):325-330.

11. Vargas CR, Koolen PGL, Ho OA, et al. Tumescent mastectomy technique in autologous breast reconstruction. Journal of Surgical Research. 2015;198(2):525-529.

12. Heister M, Hafner HM, Breuninger $H$, et al. Tumescent local anaesthesia for early dermatosurgery in infants. Journal of the European Academy of Dermatology and Venereology : JEADV. Dec 2017;31(12):2077-2082.

13. Conroy PH, O'Rourke J. Tumescent anaesthesia. The surgeon : journal of the Royal Colleges of Surgeons of Edinburgh and Ireland. Aug 2013;11(4):210-221.

14. Craig SB, Concannon MJ, McDonald GA, Puckett CL. The antibacterial effects of tumescent liposuction fluid. Plastic and reconstructive surgery. Feb 1999;103(2):666-670.

15. Klein JA. Antibacterial effects of tumescent lidocaine. Plastic and reconstructive surgery. Nov 1999;104(6):1934-1936.

16. Ikuta PT, Raza SM, Durrani Z, Vasireddy AR, Winnie AP, Masters RW. pH adjustment schedule for the amide local anesthetics. Regional anesthesia. Sep-Oct 1989;14(5):229235.

17. Stewart JH, Cole GW, Klein JA. Neutralized lidocaine with epinephrine for local anesthesia. The Journal of dermatologic surgery and oncology. Oct 1989;15(10):10811083. 
medRxiv preprint doi: https://doi.org/10.1101/2020.08.10.20170720; this version posted August 14, 2020. The copyright holder for this preprint (which was not certified by peer review) is the author/funder, who has granted medRxiv a license to display the preprint in perpetuity. All rights reserved. No reuse allowed without permission.

18. Stewart JH, Chinn SE, Cole GW, Klein JA. Neutralized lidocaine with epinephrine for local anesthesia--II. The Journal of dermatologic surgery and oncology. Sep 1990;16(9):842-845.

19. Masters JE. Randomised control trial of $\mathrm{pH}$ buffered lignocaine with adrenaline in outpatient operations. British journal of plastic surgery. Jul 1998;51(5):385-387.

20. Breuninger H, Wehner-Caroli J. Slow infusion tumescent anesthesia. Dermatologic surgery : official publication for American Society for Dermatologic Surgery [et al.]. Jul 1998;24(7):759-763.

21. Breuninger H, Hobbach PS, Schimek F. Ropivacaine: an important anesthetic agent for slow infusion and other forms of tumescent anesthesia. Dermatologic surgery : official publication for American Society for Dermatologic Surgery [et al.]. Oct 1999;25(10):799802.

22. Khater A, Mazy A, Gad M, Eldayem OTA, Hegazy M. Tumescent mastectomy: The current indications and operative tips and tricks. Breast Cancer: Targets and Therapy. 2017;9:237-243.

23. Ostad A, Kageyama N, Moy RL. Tumescent anesthesia with a lidocaine dose of $55 \mathrm{mg} / \mathrm{kg}$ is safe for liposuction. Dermatologic surgery : official publication for American Society for Dermatologic Surgery [et al.]. Nov 1996;22(11):921-927.

24. Klein JA, Jeske DR. Estimated Maximal Safe Dosages of Tumescent Lidocaine. Anesthesia and analgesia. May 2016;122(5):1350-1359.

25. Rao RB, Ely SF, Hoffman RS. Deaths related to liposuction. The New England journal of medicine. May 13 1999;340(19):1471-1475.

26. Kaminer MS. Tumescent Liposuction Council Bulletin, November, 2000. Dermatologic surgery : official publication for American Society for Dermatologic Surgery [et al.]. 2001;27(6).

27. Lehnhardt M, Homann HH, Daigeler A, Hauser J, Palka P, Steinau HU. Major and lethal complications of liposuction: a review of 72 cases in Germany between 1998 and 2002. Plastic and reconstructive surgery. Jun 2008;121(6):396e-403e.

28. Hanke CW, Bernstein G, Bullock S. Safety of tumescent liposuction in 15,336 patients. National survey results. Dermatologic surgery : official publication for American Society for Dermatologic Surgery [et al.]. May 1995;21(5):459-462.

29. Housman TS, Lawrence N, Mellen BG, et al. The safety of liposuction: Results of a national survey. Dermatologic Surgery. 2002;28(11):971-978.

30. Scarborough DA, Herron JB, Khan A, Bisaccia E. Experience with more than 5,000 cases in which monitored anesthesia care was used for liposuction surgery. Aesthetic plastic surgery. Nov-Dec 2003;27(6):474-480.

31. Habbema L. Safety of liposuction using exclusively tumescent local anesthesia in 3,240 consecutive cases. Dermatologic surgery : official publication for American Society for Dermatologic Surgery [et al.]. Nov 2009;35(11):1728-1735.

32. Boeni R. Safety of tumescent liposuction under local anesthesia in a series of 4,380 patients. Dermatology (Basel, Switzerland). 2011;222(3):278-281.

33. Fischer G. Liposculpture: the "correct" history of liposuction. Part I. The Journal of dermatologic surgery and oncology. Dec 1990;16(12):1087-1089.

34. Chun YS, Verma K, Rosen H, et al. Use of tumescent mastectomy technique as a risk factor for native breast skin flap necrosis following immediate breast reconstruction. American journal of surgery. Feb 2011;201(2):160-165. 
medRxiv preprint doi: https://doi.org/10.1101/2020.08.10.20170720; this version posted August 14, 2020. The copyright holder for this preprint

(which was not certified by peer review) is the author/funder, who has granted medRxiv a license to display the preprint in perpetuity.

All rights reserved. No reuse allowed without permission.

35. Seth AK, Hirsch EM, Fine NA, et al. Additive risk of tumescent technique in patients undergoing mastectomy with immediate reconstruction. Annals of surgical oncology. Oct 2011;18(11):3041-3046.

36. Malik O, Kaye AD, Kaye A, Belani K, Urman RD. Emerging roles of liposomal bupivacaine in anesthesia practice. Journal of anaesthesiology, clinical pharmacology. Apr-Jun 2017;33(2):151-156.

37. Frank SG, Lalonde DH. How acidic is the lidocaine we are injecting, and how much bicarbonate should we add? The Canadian journal of plastic surgery = Journal canadien de chirurgie plastique. Summer 2012;20(2):71-73.

38. Zelickson BR, Goldberg LH, Rubenzik MK, Wu WJ, Sinai M. Parallel, minimal needleinsertion technique for achieving a painless injection of local anesthetic. Journal of the American Academy of Dermatology. Aug 2017;77(2):369-370.

39. Spring MA, Stoker DA, Holloway J, Weintraub M, Stevens WG. Office-based plastic surgery with general anesthesia: efficiency of cost and time. Seminars in plastic surgery. May 2007;21(2):99-101.

40. Kutas B, Ozdemir F, Tezcan O, et al. Does the direction of tumescent solution delivery matter in endovenous laser ablation of the great saphenous vein? Ther Adv Cardiovasc Dis. Dec 2015;9(6):397-402.

41. Dzieciuchowicz L, Espinosa G, Grochowicz L. Evaluation of ultrasound-guided femoral nerve block in endoluminal laser ablation of the greater saphenous vein. Ann Vasc Surg. Oct 2010;24(7):930-4.

42. Gunes T, Altin F, Kutas B, et al. Less painful tumescent solution for patients undergoing endovenous laser ablation of the saphenous vein. Annals of vascular surgery. Aug 2015;29(6):1123-1127.

43. Dumantepe M, Uyar I. Comparing cold and warm tumescent anesthesia for pain perception during and after the endovenous laser ablation procedure with $1470 \mathrm{~nm}$ diode laser. Phlebology. Feb 2015;30(1):45-51.

44. Abud B, Karaarslan K, Turhan S, Karaman Y. Is the temperature of tumescent anesthesia applied in the endovenous laser ablation important? comparison of different temperatures for tumescent anesthesia applied during endovenous ablation of incompetent great saphenous vein with a $1470 \mathrm{~nm}$ diode laser. Vascular. Dec 2014;22(6):421-426.

45. Pronk P, Gauw SA, Mooij MC, et al. Randomised controlled trial comparing saphenofemoral ligation and stripping of the great saphenous vein with endovenous laser ablation (980 nm) using local tumescent anaesthesia: one year results. European journal of vascular and endovascular surgery: the official journal of the European Society for Vascular Surgery. Nov 2010;40(5):649-656.

46. Saha S, Tiwari A, Hunns C, Refson J, Abidia A. Efficacy of topical local anaesthesia to reduce perioperative pain for endovenous laser ablation of varicose veins: a double-blind randomized controlled trial. Therapeutic advances in cardiovascular disease. Aug 2016;10(4):251-255.

47. Jibiki M, Miyata T, Futatsugi S, Iso M, Sakanushi Y. Effect of the wide-spread use of endovenous laser ablation on the treatment of varicose veins in Japan: a large-scale, single institute study. Laser therapy. Oct 01 2016;25(3):171-177.

48. Memetoglu ME, Kurtcan S, Kalkan A, Özel D. Combination technique of tumescent anesthesia during endovenous laser therapy of saphenous vein insufficiency. Interactive cardiovascular and thoracic surgery. 2010;11(6):774-777. 
medRxiv preprint doi: https://doi.org/10.1101/2020.08.10.20170720; this version posted August 14, 2020. The copyright holder for this preprint (which was not certified by peer review) is the author/funder, who has granted medRxiv a license to display the preprint in perpetuity. All rights reserved. No reuse allowed without permission.

49. Hamel-Desnos C, Desnos P, Allaert FA, Kern P. Thermal ablation of saphenous veins is feasible and safe in patients older than 75 years: A prospective study (EVTA study). Phlebology. Sep 2015;30(8):525-532.

50. Pannier F, Rabe E, Rits J, Kadiss A, Maurins U. Endovenous laser ablation of great saphenous veins using a $1470 \mathrm{~nm}$ diode laser and the radial fibre - Follow-up after six months. Phlebology. 2011;26(1):35-39.

51. van Zandvoort CE, Toonder IM, Stoopendaal IA, Wittens $\mathrm{CH}$. The effect of distraction on pain perception during an endovenous thermal ablation procedure. Phlebology. Aug 2016;31(7):463-470.

52. Wallace T, Leung C, Nandhra S, Samuel N, Carradice D, Chetter I. Defining the optimum tumescent anaesthesia solution in endovenous laser ablation. Phlebology. Jun 2017;32(5):322-333.

53. Rasmussen LH, Bjoern L, Lawaetz M, Blemings A, Lawaetz B, Eklof B. Randomized trial comparing endovenous laser ablation of the great saphenous vein with high ligation and stripping in patients with varicose veins: short-term results. Journal of vascular surgery. Aug 2007;46(2):308-315.

54. Proebstle TM, Vago B, Alm J, Göckeritz O, Lebard C, Pichot O. Treatment of the incompetent great saphenous vein by endovenous radiofrequency powered segmental thermal ablation: First clinical experience. Journal of vascular surgery. 2008;47(1):151156.e151.

55. Kendler M, Simon JC, Wetzig T. Local anesthesia with lidocaine and prilocaine, using the tumescent technique, for the radiofrequency ablation of lower extremity varicose veins. International journal of dermatology. Jun 2013;52(6):739-744.

56. Krasznai AG, Sigterman TA, Willems CE, et al. Prospective study of a single treatment strategy for local tumescent anesthesia in muller phlebectomy. Annals of vascular surgery. 2015;29(3):586-593.

57. Smith SR, Goldman MP. Tumescent anesthesia in ambulatory phlebectomy. Dermatologic surgery : official publication for American Society for Dermatologic Surgery [et al.]. Apr 1998;24(4):453-456.

58. Creton D, Réa B, Pittaluga P, Chastanet S, Allaert FA. Evaluation of the pain in varicose vein surgery under tumescent local anaesthesia using sodium bicarbonate as excipient without any intravenous sedation. Phlebology. 2012;27(7):368-373.

59. Schmeller W, Hueppe M, Meier-Vollrath I. Tumescent liposuction in lipoedema yields good long-term results. The British journal of dermatology. Jan 2012;166(1):161-168.

60. Augustin M, Maier K, Sommer B, Sattler G, Herberger K. Double-blind, randomized, intraindividual comparison study of the efficacy of prilocaine and lidocaine in tumescent local anesthesia. Dermatology (Basel, Switzerland). 2010;221(3):248-252.

61. Kaplan B, Moy RL. Comparison of room temperature and warmed local anesthetic solution for tumescent liposuction. A randomized double-blind study. Dermatol Surg. Aug 1996;22(8):707-9.

62. Bertelsen CA. Cleft-lift operation for pilonidal sinuses under tumescent local anesthesia: a prospective cohort study of peri- and postoperative pain. Diseases of the colon and rectum. Jul 2011;54(7):895-900.

63. Prasetyono TOH, Lestari PA. The onset and duration of action of $0.2 \%$ lidocaine in a oneper-mil tumescent solution for hand surgery. Archives of plastic surgery. 2016;43(3):272277. 
medRxiv preprint doi: https://doi.org/10.1101/2020.08.10.20170720; this version posted August 14, 2020. The copyright holder for this preprint (which was not certified by peer review) is the author/funder, who has granted medRxiv a license to display the preprint in perpetuity. All rights reserved. No reuse allowed without permission.

64. Ceran C, Aksam B, Aksam E, Demirseren ME. Selective Nerve Block Combined With Tumescent Anesthesia. The Journal of hand surgery. Dec 2015;40(12):2339-2344.

65. Goodman G. Dermabrasion using tumescent anesthesia. The Journal of dermatologic surgery and oncology. Dec 1994;20(12):802-807.

66. Budamakuntla L, Loganathan E, George A, Revanth B, Sankeerth V, Sarvjnamurthy S. Comparative study of efficacy and safety of botulinum toxin a injections and subcutaneous curettage in the treatment of axillary hyperhidrosis. Journal of cutaneous and aesthetic surgery. 2017;10(1):33-39.

67. Cartee TV, Schleich M, Helm KF. Granuloma Annulare Arising in Tumescent Anesthesia Injection Sites After Endovenous Ablation. Dermatologic surgery : official publication for American Society for Dermatologic Surgery [et al.]. Oct 2015;41(10):1184-1186.

68. Theivacumar NS, Gough MJ. Arterio-venous fistula following endovenous laser ablation for varicose veins. European journal of vascular and endovascular surgery : the official journal of the European Society for Vascular Surgery. Aug 2009;38(2):234-236.

69. Hirokawa M, Kurihara N. Comparison of Bare-Tip and Radial Fiber in Endovenous Laser Ablation with $1470 \mathrm{~nm}$ Diode Laser. Annals of vascular diseases. 2014;7(3):239-245.

70. Ostler AE, Holdstock JM, Harrison CC, Whiteley MS. Arterial false aneurysm in the groin following endovenous laser ablation. Phlebology. Apr 2015;30(3):220-222.

71. Spornraft-Ragaller $P$, Stein A. Contact dermatitis to prilocaine after tumescent anesthesia. Dermatologic surgery : official publication for American Society for Dermatologic Surgery [et al.]. Aug 2009;35(8):1303-1306.

72. Hubmer MG, Koch H, Haas FM, Horn M, Sankin O, Scharnagl E. Necrotizing fasciitis after ambulatory phlebectomy performed with use of tumescent anesthesia. Journal of vascular surgery. Jan 2004;39(1):263-265.

73. Wollina U, Heinig B, Nowak A. Treatment of elderly patients with advanced lipedema: a combination of laser-assisted liposuction, medial thigh lift, and lower partial abdominoplasty. Clinical, cosmetic and investigational dermatology. 2014;7:35-42.

74. Hanke W, Cox SE, Kuznets N, Coleman IWP. Tumescent liposuction report performance measurement initiative: National survey results. Dermatologic Surgery. 2004;30(7):967977.

75. Beeson WH, Slama TG, Beeler RT, Rachel JD, Picerno NA. Group A streptococcal fasciitis after submental tumescent liposuction. Archives of facial plastic surgery. Oct-Dec 2001;3(4):277-279.

76. Gilliland MD, Coates N. Tumescent liposuction complicated by pulmonary edema. Plastic and reconstructive surgery. Jan 1997;99(1):215-219.

77. Prasetyono TO, Koswara AF. Linear Hand Burn Contracture Release under Local Anesthesia without Tourniquet. Hand surgery : an international journal devoted to hand and upper limb surgery and related research : Journal of the Asia-Pacific Federation of Societies for Surgery of the Hand. Oct 2015;20(3):484-487.

78. Boni R.Tumescent liposuction: efficacy of a lower lidocaine dose (400 mg/l). Dermatology.2010;220(3):223-5 